\title{
Reading Across Cultures: Global Narratives, Hotels and Railway Stations
}

\author{
Ulrike C. Zitzlsperger ${ }^{1}$ (D)
}

Received: 18 September 2015/ Accepted: 22 December 2015/Published online: 13 January 2016

(C) The Author(s) 2016. This article is published with open access at Springerlink.com

\begin{abstract}
This article takes its cue from the English critic, novelist and painter John Berger. He argues that what we know determines what we see. Hotels and railway stations, though they differ in size, design and appearance, are places of temporary national and international congress that are recognized by everyone. They become visible or even iconic once their history or their role is turned into at least part of a wider narrative-in literature, film or in other arts. This provides a representative focus by which we may read a city's or a nation's past. In exemplifying such connections I focus first on the long-term history of Friedrichstraße station and some of the surrounding hotels in the context of the history of Berlin, situating them within the national and, by implication, also the international context. Secondly, I will consider the outbreak of the First World War in 1914 as an event in which the role of railway stations generated both personal and collective memories across cultures and over several decades.
\end{abstract}

Keywords Railway station · Hotel · John Berger · Berlin · Friedrichstraße · Adlon · Sven Hedin · Ernst Toller · George Orwell · Julius Posener

Ulrike C. Zitzlsperger

u.c.zitzlsperger@exeter.ac.uk

1 College of Humanities/Modern Languages, University of Exeter, Queen's Building, Exeter EX4 4QH, England, UK 


\section{Introduction}

In 1972, first as a ground-breaking series on the BBC and then in book form, John Berger discussed Ways of Seeing the arts. He argued that "what we know or what we believe" affects "the way we see things" $(1972,8) .{ }^{1}$ While Berger is primarily concerned with works of art, this, I argue, also applies to semi-public spaces such as restaurants, cafés, cinemas, museums, hotels and here in particular railway stations, which are locations with which we are all familiar: we grow up with them, we perceive them as part of our daily routines and we tend to take them for granted. What is more: any holiday, business trip or extended stay abroad is structured by such spaces and the particular itinerary they dictate-from the station (or the airport) to a hotel, from there to a museum or a theatre and so on. The history of such places may add meaning to their functionality - the information that particular individuals passed through a hotel or a railway station or major events unfolded there changes the meaning of the location in our minds and turns it into an active place of interest or even commemoration.

It is easy to relate to these locations once they form part of a narrative since their layout follows the same architectural principle wherever we go: in a hotel we enter a reception area and it is only from here that we will, with the help of stairs and lifts, approach our room as a temporary private space; we reach the platform of the railway station by entering the station building, passing the ticket offices or machines; the café will always be divided into a seating area and the bar, where the owner and his employees remain in charge. Berger's observations-which were inspired by the German philosopher Walter Benjamin and his essay "The Work of Art in the Age of Mechanical Reproduction"-hold true for our understanding of the mechanics of semi-public spaces: "Seeing comes before words"; the understanding of structural principles goes hand in hand with the knowledge that the same rules apply more or less everywhere, and it is only the narratives attached to these buildings at certain times that lend them their individuality. In the process, however, the semi-public spaces come to illustrate our observations: we "understand" them-in Berger's words-and we can rely on the fact that their principle mechanisms are understood by everybody $(1972,33,28)$.

We associate hotels and railway stations, much later also cinemas and airports, with modernity-rail and steam together had been driving forces of the nineteenth and early twentieth centuries and as such they played and play a major role in the history of nation building. Such spaces are, then, also indicative of a nation's political and cultural history. ${ }^{2}$ An engagement with the history of a specific location may be embedded in a wider national context; a national situation may, in turn, be set against the international. This process is made visible when such spaces are depicted in an iconic, either unique or typical, moment-be it in a journalistic piece

\footnotetext{
${ }^{1}$ He continues: "Yet this seeing which comes before words, and can never be quite covered by them, is not a question of mechanically reacting to stimuli. [...] We only see what we look at. To look is an act of choice. [...] To touch something is to situate oneself in relation to it."

2 The role of such spaces has been researched in the context of the spatial turn; modernity; and in relation to the interpretation of history. Relevant literature includes: Augé (2006); Warf and Arias (2009); Geisthövel and Koch (2005); Kaschuba (2004); Schivelbusch (2007); Schlögel (2006).
} 
reporting about an international gathering in a hotel, a novel stressing moments of arrival or departure at a railway station, a painting that captures the arrival of commuters after work at the station, or a photograph that records in permanence the moment when a new airport is opened to the public. From that moment on the image acts as a reference point, an agreeable means of association for the wider community.

To illustrate this point of captivating public imagination and the spirit of the time one might refer, for example, to Claude Monet's 1877 painting of Saint-Lazare railway station in Paris. The painting is one of seven canvases he displayed in an Impressionist exhibition that year-making the station an integral and distinctive part of the city and guiding the eye towards essential features: the lightness of the background in contrast with the heavy locomotives, a glimpse of the cityscape and the fragility of man within this cityscape bare of nature and, instead, characterized by the steam that at the time signalled progress rather than pollution. Monet was not alone in his engagement with the new technological and social landscape of the nineteenth century: William Powell Frith in England and Hans Baluschek in Germany are among many who highlighted both the sense of progress and of fundamental change that the "Cathedrals of Modernity" brought about. It is no coincidence that the much fought-for object of desire in Sergio Leone's film Once Upon a Time in the West (1968) is the planned station building in a future boom town along the railway tracks.

At this point Berger's Ways of Seeing come into play again: if what we know determines what we see, one of the fascinating aspects of hotels and railway stations - to focus on two particularly interesting semi-public spaces-as cultural and technical artefacts is that their significance translates across cultures and they may therefore serve as entry points for understanding what is familiar on the one hand and different on the other. We all, for example, recognize the symbolic importance of a clock tower next to a railway station, be it Waterbury Union Station (United States); King's Cross (London, England); the Central Railway Clock Tower (Sydney, Australia); Toledo (Spain); or Beijing (China)—all indicative of railways transcending space and time; and we respond with awe when we see a grand entrance hall with high ceilings, ornate windows and beautiful columns-be it in a hotel, or a railway station such as Antwerp (Belgium), St Pancras International (London, England), Chhatrapati Shivaji Terminus Mumbai (India), Gare du Nord (Paris, France) or New York's Grand Central Terminal (USA).

If we consider the example of Antwerp (1895-1905), the message of the overwhelming and ornate station is clear: it functions, like a palace, as a focus in the surrounding city-and it has been possible to buy postcards of it ever since the station was first built, so that the image, a marker of Antwerp's success and of civic pride, is shared across regions and countries. Thanks to the impressively grand staircase, the moment of entering and leaving the railway station is theatrical, and the centrepiece of the commanding clock, a typical feature of railway stations, embeds the station in the here and now - this is not just a breathtakingly beautiful setting but, given Belgium's position at the turn of the century, very clearly a commercial one. 
By way of illustration of the impact of these observations I shall now focus first on one particular railway station in Berlin, Bahnhof Friedrichstraße. Friedrichstraße was and is at the centre of the German capital although it is neither the oldest nor the most modern of the stations in Berlin. I aim to show in a variety of examples how the treatment of Friedrichstraße station and the surrounding luxury hotels explicitly link it with Berlin's and Germany's history, and indeed sum it up. Secondly, beyond the narrative of the individual location, in global configurations the literary and artistic treatment of the station also exemplifies why semi-public spaces may serve as an example of widely applicable cross-cultural patterns of culture.

\section{Berlin Friedrichstraße and Beyond: Space Over Time}

Building work for Berlin Friedrichstraße began in 1878 during the post-FrancoPrussian war boom years, and the station opened for business only 4 years later in 1882. Right from the beginning it benefited from its central position in the lively Friedrichstraße, which was known for all the attractions of commercial Berlin by day, followed by a thriving nightlife including cafés, restaurants, cinemas, cabarets and theatres. Peter Neumann (2004) has described the station as Berlin's "secret main station" - though its image changed over time. Quoting the writer Jens Sparschuh, Neumann acknowledges that between 1961 and 1989 the same station was to become Berlin's most "absurd railway station".

Back in the late nineteenth century, however, the design of the main hall was forward-looking, among the first to utilize electric light. One of the hotels in the more immediate neighbourhood of the station was the Central, which opened in 1877 , consciously attempting to emulate what was then the far more trendy style of hotels in Paris, London and New York. The Central, built in 1880/81, housed the Wintergarten, one of Berlin's most important modern variety theatres and among the first to show "moving images". In 1887 it offered 600 rooms, in due course three lifts and its own tourist office. To add to the feeling of a tourist destination the Central housed a wide range of gastronomy that mirrored the style of other popular destinations in Germany, including Bavaria and the Black Forest, the Rhineland and Silesia. A contemporary image from around 1910 highlights its prime position right next to the station (Central Bahnhof Friedrichstraße); others embed the hotel between the Brandenburg Gate and the station (Fig. 1).

The late nineteenth century was a time of new beginnings both for Germany and for Berlin, since 1871 capital of the German Empire. Both the emerging department stores and the numerous large and small new railway stations of the time reflect national ambitions. Wolfgang Schivelbusch compares them to a threshold (Schwellenort) between a city and the unlimited beyond (2007); the French anthropologist Marc Augé ranks them among the non-spaces (that is, potentially meaningless and mere transitional) of modern society (2006); and the German historian Karl Schlögel focuses on their importance for an understanding of national histories (2006). It is, then, hardly a coincidence that in 1911 the politically controversial Swedish geographer, explorer and travel writer Sven Hedin 


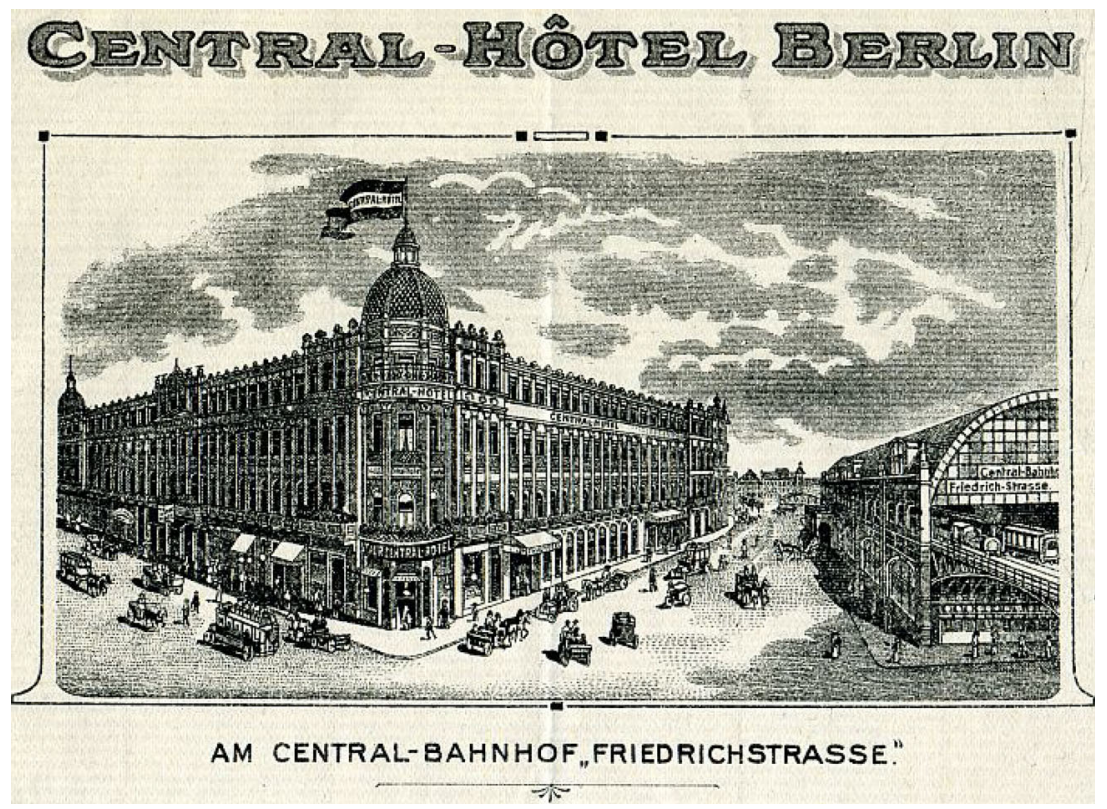

Fig. 1 Central Hotel (image in the public domain)

(1865-1952) used this very station as a starting point for his account-From Pole to Pole-of his travels between the 1880s and the early 1900s. For generations of German readers-often young readers-his book, its photographs and illustrations provided, for example, a first and often only account of China-including descriptions of the Chinese railway system, the universities and the Great Wall.

Hedin pays close attention to just one railway station. Berlin Friedrichstraße is where his report starts and although the ceaseless noise disturbs him, he uses a bird's eye view to zoom into the heart of a complex topography:

If we spread out a map of the [European] railways, we perceive a network of black lines [...]. At the cross-sections are cities. In the north of Germany this network of lines becomes ever more dense and its very centre may be compared to a spider in the middle of its web. This spider is Berlin [...]. By the railways, Berlin draws in life and traffic not just from Germany but from the whole of Europe and indeed the whole world. (Hedin 1926, 4-5) ${ }^{3}$

3 years before the outbreak of the First World War in 1914, the very heart of the buzzing metropolis is clearly defined: "In the centre of Berlin is a station, Friedrichstraße station, a massive hall of iron and glass with a number of parallel tracks in between platforms." (Hedin 1926, 6-7) (Fig. 2).

Hedin reports for readers who do not yet travel and his account puts the station and the metropolis on the map: for them such depictions express the modernity of Berlin-iron and glass were the new building materials that facilitate eye-catching

\footnotetext{
3 Translations of excerpts from Hedin's book into English are by the author of this article.
} 


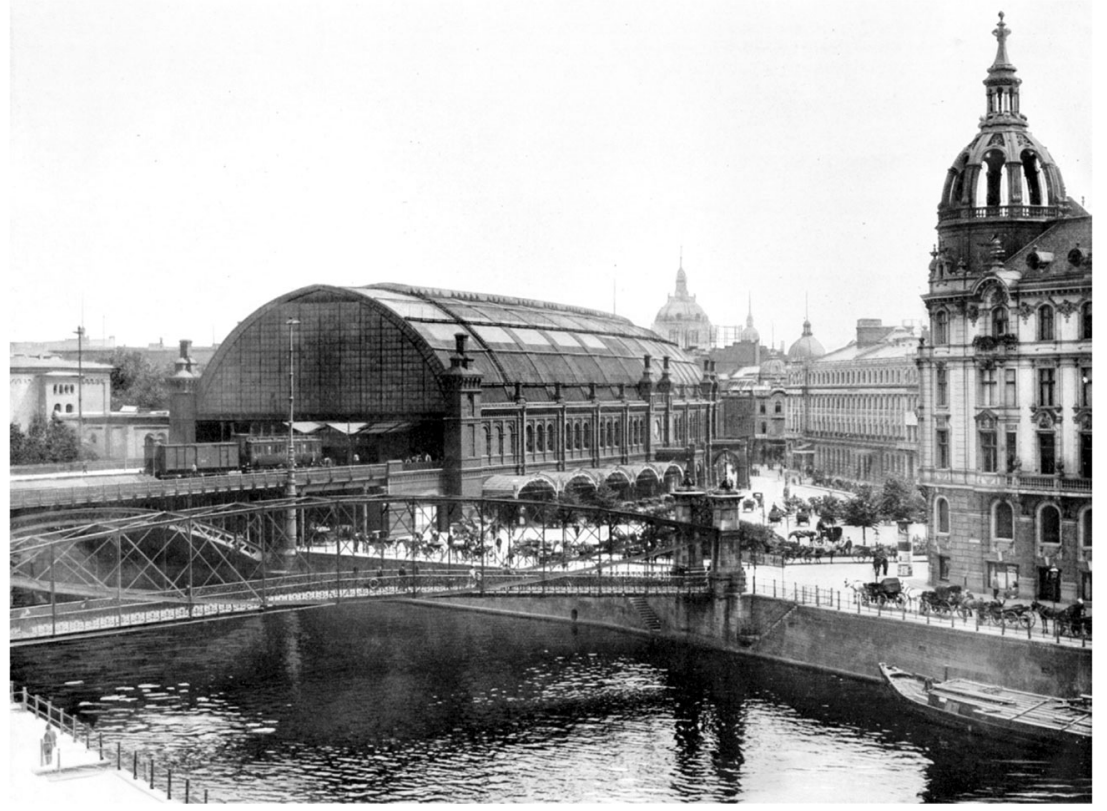

Fig. 2 Friedrichstraße station around 1900 (image in the public domain)

architecture and sophisticated engineering alike. Hedin further enhances this impression by his evocation of the crowds filling what is the very heart of the metropolis:

People rush in and out of the station constantly, up the stairs and down again, they form long queues at the ticket offices and employees with luggage on their backs push through these crowds. The gigantic hall, where express trains arrive and depart, is filled with deafening noise. $(1926,7)$

Hedin's description combines the modern with a sense of the fantastic-although the latter can at all times be verified. Berlin Friedrichstraße, prominently placed in the introduction, is the benchmark against which the rest of the world will be measured. His depiction is representative of an age when railway stations were indeed considered the epitome of modernity, progress and civilization-a sense of exuberance that was to change dramatically during the First World War when the same stations became for the soldiers the gateway to the front. ${ }^{4}$ In the 1920 s railway stations nevertheless kept their hold on the public's imagination-after all, trains remained the main means of transport, not least for politicians and contemporary celebrities. Corey Ross describes Charlie Chaplin's arrival in 1931 at Friedrichstraße which, by courtesy of thousands of enthusiastic fans who sought to celebrate the star of City Lights, has turned into a "besieged fortress" (2010, 1): the railway

\footnotetext{
${ }^{4}$ On the importance of railway stations during and after the war see Richards and MacKenzie (1986) and Zitzlsperger (2013), here chapter 2.
} 
station serves as a hub, the obvious meeting point to welcome the famous guest from faraway Hollywood.

Many of the hotels close to Friedrichstraße feature as iconic places in the cultural map of the 1920s and 1930s — not least thanks to their closeness to the station. Unlike today's generic hotel chains, luxurious and in particular Grand Hotels were understood well into the early 1930s as an international yet exclusive space of culture that fostered networks in Europe and beyond: the writer Vicki Baum $(2007,2008)$ was able to play on popular knowledge about Grand Hotels, first in Menschen im Hotel (1929), set in Berlin, then, following the same principles, in Hotel Shanghai (1937), based on the Cathay (today Fairmont Peace Hotel).

The Adlon, just a few minutes away from Friedrichstraße station and soon a place of considerable competition for the Central, had opened in 1907 in a unique position on Unter den Linden next to the Brandenburg Gate. The philosophy of the Adlon followed the American hotel model, ${ }^{5}$ including novelties such as in-house laundry and the generation of the hotel's own electricity; access for the wider public to the ground floor rooms, in particular the bar. In the 1920s, as well as politicians and businessmen, the hotel welcomed as guests national and international celebrities such as Charlie Chaplin, Emil Jannings, Josephine Baker, Marlene Dietrich and Thomas Mann. Mann, like many of his affluent contemporaries, was a frequent guest in Europe's Grand Hotels and indeed an asset to their reputation-be it the Baur au Lac and the Dolder Grand Hotel in Zürich, the Continental in Munich, the Frankfurter Hof in Frankfurt/Main, the Grand Hôtel des Bains in Venice, Huis ter Duin in Noordwijk aam Zee or the Waldhaus in Sils-Maria. Mann's works are littered with references to real and imaginary Grand Hotels and they frequently served him as a first platform to introduce a select audience to new texts. Indeed, hotels featuring in journalism and literature may come to define a place for a certain time-Graham Greene's Continental in Saigon, the Metropole in Hanoi, the City in Freetown or Hotel Sacher in Vienna are representative examples.

Spatial characteristics of such international Grand Hotels include prominent entrance halls; eye-catching staircases; well-lit dining rooms; or, later on, a bar. Architecture and design are programmatic, and despite an individual hotel's particular design and history, recognition of ground-breaking luxury as an indicator of international standards was fundamental. Elaine Denby records about the Adlon:

Two architects with hotel-building experience elsewhere in Berlin collaborated on the Adlon, large in size by European standards, with 305 bedrooms and 140 private bathrooms: Carl Gause, also designer of the Bristol, and Robert Leibnitz with the Hotel Cumberland to his credit, made use of the Schinkel neo-classical tradition and created a well-articulated building faced

\footnotetext{
5 While the spectrum of American luxury hotels is wide, for Europe New York's Waldorf Astoria (1893) was particularly influential, not least because of highly efficient service. See, for example, Kaplan (2006). Molly Berger's study shows how American hotel innovations throughout the nineteenth and early twentieth centuries reflected the standing of cities. Hotels facilitated predominantly technological luxuries often well before they found their way into private homes-as such luxury was closely linked to the success story of American capitalism and an understanding of a progressive civilization (Berger 2011). For a general overview on hotels also see Denby (1998). On hotels as a building type see Pevsner (1979, 169-192). On German Grand Hotels Schmitt (1982) and Wenzel (1991).
} 
with substantial stonework and built around an attractive courtyard lightened by decorative carving. (1998, 265)

In Paris, César Ritz capitalized on existing buildings with façades designed by the French royal architect of the seventieth century, Jules Hardouin-Mansart, whose works also include extensions to Versailles, while the Peace Hotel in Shanghai, a thoroughly modern 1920s construction, includes an eye-catching pyramidal roof that still enhances its role as a landmark at the Bund. In each Grand Hotel, no matter where, there is the need for eye-catching architecture, but also cutting edge technology and trend-setting developments. This included the use of lifts and the provision of elaborate lighting and bathrooms with running water. The Ritz offered not only telephones in each room but also en-suite bathrooms, just one of the new approaches to maximize the guests' sense of hygiene, while the Cathay facilitated personal sound recordings of special events.

By design such luxurious hotels therefore invite - then as now-the performance of an exclusive life-style-one that is not just based on comfort, but also a reflection of advances in society and of contemporary expectations. Jennifer M. Volland states for the Grand Hotel between 1830 and 1930:

Here denizens of the wealthy and privileged congregated in an illusory "other world". The hotels of this period were consummate examples of Michel Foucault's heterotopias. Perceived as autonomous spheres, they obscured one's sense of space and time, and gave the perception that what happened inside could-and did-only happen there. According to Foucault these "counter-sites" exist in every culture, juxtaposed with and distinguishing themselves from utopias. $(2013,16)$

It is for this reason that luxury hotels make for particularly interesting international comparisons, though it is important to bear in mind that, contrary to the concept of such "counter-sites", many hotels at this point adopted the American model of opening its offers to the wider public_as, for example, the famous bar in the Adlon.

The reputation of luxury associated with Grand Hotels feeds off public imagination - a land of plenty that can be firmly located. However, while the hotel is a closed system in practice, its reputation as a theatre of personal, regional and national aspirations enhances its effect internationally. Grand Hotels in particular foster anecdotal moments of personal encounters, but also a long list of exceptional culinary and technological improvements that in the first third of the twentieth century catered for a new generation of worldly travellers. It is of little relevance whether for example the cocktail Bloody Mary was really invented in the Ritz. ${ }^{6}$ What is of importance is that the luxurious hotel qualifies as the most fitting place to locate new beginnings.

Lorenz Adlon's modern hotel, a beacon of technological advancement, responded well to Kaiser Wilhelm II's ambitious plans for Germany. Adlon had sufficiently impressed the Kaiser for him to advise that a building (Palais Redern) designed by Karl Friedrich Schinkel should be pulled down to provide the space for

\footnotetext{
${ }^{6}$ Locations competing for the first Bloody Mary to have been created are the New York Bar, later Harry's New York Bar and Hemingway's Bar in the Ritz and the 21 Club in New York.
} 
the new hotel. Adlon's Grand Hotel, a material icon of society (François and Schulze 2001, vol. 1, 17-18), was firmly embedded in an implicit understanding and projection of complex cultural meanings-here, that the "old", even the work of the city's most famous and influential architect, had become obsolete. When, in the final days of the Second World War, the Adlon served as a reliable shelter against Allied bombing and as a field hospital for the many wounded, the house again became integral to the history of Berlin. The fire on the 2 May 1945, blamed on drunken Soviet soldiers, mirrored the destruction of Berlin.

Like the Adlon, Friedrichstraße station was nearly destroyed during the Second World War. The Berlin writer Ingeborg Drewitz, overwhelmed by memories of the 1920s, 1930s and the realities of the 1940s, uses the station time and again for a breathless panorama of the city's history: She remembers the arrival of Charlie Chaplin and trains from Paris, Cologne and Hanover on the way to Warsaw and Brest-Litovsk: "The city", she writes, "was in the middle of Europe and the centre of the city was Friedrichstraße station". She paints, juxtaposing images, a detailed picture of the scene at the end of the war:

What remained were iron skeletons, the smell of death, executed men and the balalaikas of the victors. Women with barrows, women piling rubble, potato peel and turnip soup, dysentery and typhus, tuberculosis, vocabulary for hunger, for summer and winter. And then without further ado Mozart in the undestroyed theatre next to the Friedrichstraße station. $(1992,7,8)^{7}$

The image of the station allows Drewitz to reduce the complexities of years of challenges and developments to one space that has meaning for everyone, whether they know the particular station or not.

Up to this point, then, Friedrichstraße station and the surrounding hotels served to familiarize readers and viewers first with an ambitious modern nineteenth-century metropolis; then a meeting point in the interwar period when Berlin turned into a cultural hub that attracted famous actors; and finally it epitomized the impact of the horror of the Second World War.

When Berlin and Germany were divided by the Wall during the Cold War in 1961, the station again served as a place of transition: a border station now within the city where two political systems, East and West, were to collide until 1989. Among the numerous writers who have commented upon the absurdity of the situation the Turkish author and dramatist Emine Sevgi Özdamar may have captured it best: travelling from West Berlin, where she lived, to East Berlin, where she trained with the theatre directors Benno Besson and Heiner Müller, she describes her amazement that after all this the weather was the same in the "other" country within the same city $(2001,55-61)$. Her account stresses the longing for the country that is so close and yet so far-one platform away. Many Berliners called Friedrichstraße in the 1960s, 70s and 80s the "station of tears" because it symbolized the ongoing separation of families.

After the fall of the Wall in 1989 and the unification of Germany in 1990, Friedrichstraße station and its surrounding area changed yet again: today's modern

\footnotetext{
7 Translation by the author of this article.
} 
station, like so many modern railway stations, offers opportunities not just to travel but also to shop. Furthermore, Friedrichstraße station now includes memorials to past history: the former building for border controls, the Palace of Tears, which Drewitz and Özdamar passed through, has been transformed into a museum that tells the story of the division of Germany. In 2008 a statue was erected in memory of the Jewish children who were forced to emigrate from here-since 2006 its counterpart has stood in Liverpool Street Station in London, where they embarked on new lives. Surrounding the station, where once the hotel Central demanded attention, a new generation of hotel chains compete for international travellers, while the rebuilt Adlon ranks among the city's leading hotels again.

Friedrichstraße station and the surrounding hotels not only exemplify a national-here: German-narrative, but its wider dimension: the functional principles of stations and hotels that serve as cultural hubs are easily recognized on a global scale; when we read their history through time, unavoidably parallels and links come to the fore that are determined by turning points throughout the nineteenth and twentieth centuries.

However, it is also possible to focus the experience of a particular time on the specific location that is provided by the semi-public space. For this purpose I will now consider three German and British writers who in the 1920s, 1940s and 1950s all chose the railway station to contextualize the impact of the outbreak of the First World War. Here too, John Berger's observation remains appropriate: railway stations were more often than not the last communal point of contact between soldiers and civilians, in due course combining peace-time memories with the realty of war. By 1918 the international community had learnt to look again at these familiar sights.

\section{Space in Time: When War Turned Real}

A decade after the end of the First World War narratives of the traumatic experience and the aftermath began to take shape. Literary treatments helped to bring to the fore topics and locations that translated both shared and individual experiences into narratives of the so-called Great War-whether life in the trenches, the importance of comradeship at the front or the efforts back home. The post-war years were transitional in nature, shaping, in turn, the need for precise temporal references in retrospective assessments of recent developments, thereby defining in a sequence of events patterns of understanding. Autobiographical writing of the 1930s, 1940s and 1950s refers in this context to the actual outbreak of War as a turning-point, a particularly formative experience.

The memory of July and August 1914, in the light of new political circumstances, relates strikingly often to arrivals and departures at railway stations- the one place soldiers and civilians shared by way of a threshold between the front and the home. To assess the international dimension of this experience I will consider three writers: the Jewish dramatist Ernst Toller (born in 1893), whose autobiography appeared in 1933; the novelist and essayist George Orwell (born in 1903), who considered the Second World War inter alia in the light of the First (1940) and 
finally the architectural historian Julius Posener (born in 1904), who sought to assess life in Germany in the aftermath of the Second World War while working in Kuala Lumpur. The three authors have two themes in common: first, their addressing the war is influenced by the memory of the outbreak of war at a railway station; secondly, this memory then forms part of an assessment of Germany's and Great Britain's status quo in the 1930s, 1940s and 1950s. Over three decades, then, memory of the outbreak of War as experienced at the railway station remains focal and it serves as a spatial marker of the end of everything that preceded it.

In 1934, 5 years before his suicide in a hotel room in New York, but already a refugee from National Socialist Germany, Toller published his autobiography with the German emigrants' publishing house of choice, Querido in Amsterdam. I Was a German. The Autobiography of a Revolutionary (Eine Jugend in Deutschland) follows events until 1924. While Toller emerged from the war as a pacifist, a leftwing politician and dramatist, his childhood and youth were conservative. He had grown up in Samootschin, where his grandfather had paid for the privilege of settling as the sole Jew. This isolated Jewish background contributes to Toller's strong sense of being German. He went on to study in France-despite the fact that his school had indoctrinated his cohort against all things French. The experience of life in France became unavoidably different and exciting:

I went to the University at Grenoble. When they addressed me as "Monsieur" I felt like some adventurer landed on a strange island after a long voyage. Every mademoiselle was an exotic princess, mysterious and inscrutable. $(1934,42)$

The sense of political change becomes-after years of anticipation abruptly palpable when Toller accompanies an Austrian friend who had been recruited after his country's declaration of war against Serbia on 28 July 1914. There is no sudden sensation that war has begun, rather a growing unease that seeks refuge in departure:

I had only one desire: to get back to Germany. At the station they told me there was a train leaving at two o'clock that night for the Swiss border. I went to a little café and waited. The war was the sole topic of conversation at all the tables. (58)

The way back from France, railway station by railway station, is a process of growing anticipation; in Geneva, he reports, "we found ourselves on Swiss soil again" and "[...] we hugged one another and sang Deutschland, Deutschland über alles. On the other side of the platform returning Frenchmen sang the Marseillaise. Outside the station a soldier was feverishly beating a little drum and announcing Swiss mobilization." (60) Each railway station is now marked by particular sentiments: in France the sheer fear of isolation on enemy territory; in Switzerland a strong bonding among the Germans returning home and in Lindau, finally back in Germany, "we burst once more into Deutschland, Deutschland über alles". (62) The shared, highly public experience at the stations during the outbreak of war affirms him as a nationalist-who, only once the horror of the battles becomes an allconsuming experience, turns into a passionate opponent of war. 
Toller is by no means alone with this kind of patriotism that becomes closely associated with the way home. In A Part of Myself. Portrait of an Epoch (Als wär's ein Stück von mir. Horen der Freundschaft, 1966) the playwright Carl Zuckmayer, at that point still at school, recalls his departure from Domburg in Holland on 31 July 1914. He observes the excitement—-despite farewell scenes and a new, military soundscape in Cologne on the way to Berlin: the euphoric, intense sensation of taking part in and being part of the collective develops at the station and is further increased by the subsequent journey. (1970, 226-228) Like Toller, Zuckmayer remembers the distinct emotional sensation at the station. Like Toller, Zuckmayer duly joined the army.

In the first instance, the railway stations allow for two things: a shared purpose with like-minded strangers that provides a sense of bonding in times of crisis. Furthermore, they are associated with the route towards safety. The memory of the outbreak of war in the context of railway stations is, however, also to be seen in alignment with the role of the railway network before 1914. Both the stations and the network were to undergo a fundamental transformation in the course of the First World War which makes the memory of the outbreak of war here all the more meaningful.

In "Entre mémoire et histoire" (1984) Pierre Nora explores-in an attempt to substantiate memory - the importance of buildings, memorials, personalities and even texts that evoke a sense of the French nation. Despite the multitude of his examples, the memory of the whole remains elusive. Material manifestations, places shared by generations on a day-to-day basis, do, however, allow for a focus of particular memories. (Erll 2011, 116) One such location is the railway station. Hailed as a marker of progress and civilization, the importance of railway lines and stations was not lost either on politicians or on the military. Developments following the Franco-Prussian War of 1870-71 are as indicative strategically as were investments in the European colonies. In due course strategic thinking did dominate: the massive, church-like railway station in Metz (1905-1908), for example, was not only an attempt to bind Alsace and Lorraine to Germany by means of architecture, but also to facilitate the speedy movement of troops as envisaged by Count Schlieffen for a forthcoming war: Metz became linked to Berlin via the "Cannons Railway". By the end of the nineteenth century the world was connected by 500,000 miles of railway, "growing at the rate of 10,000 miles per year", and they "would continue to do so until the outbreak of the First World War". (Wolmar 2009, 187) ${ }^{8}$ Following the First World War the image of trains and stations had inevitably lost its glamour; by then the military function had become far too obvious for it to be possible to believe in the betterment of Man through technology and mobility.

Toller's association of "home-coming" with the railway stations he travelled through was bound to strike a nerve with his readership. Railway stations were wellpromoted features of the national success story referred to above. The memory of cheerful troops departing to the front was, however, all the more acute. The images that Toller and Zuckmayer, but also, for example, Stefan Zweig in his recollections

\footnotetext{
${ }^{8}$ On the history of railway stations in preparation for war see also Richards and MacKenzie (1986).
} 

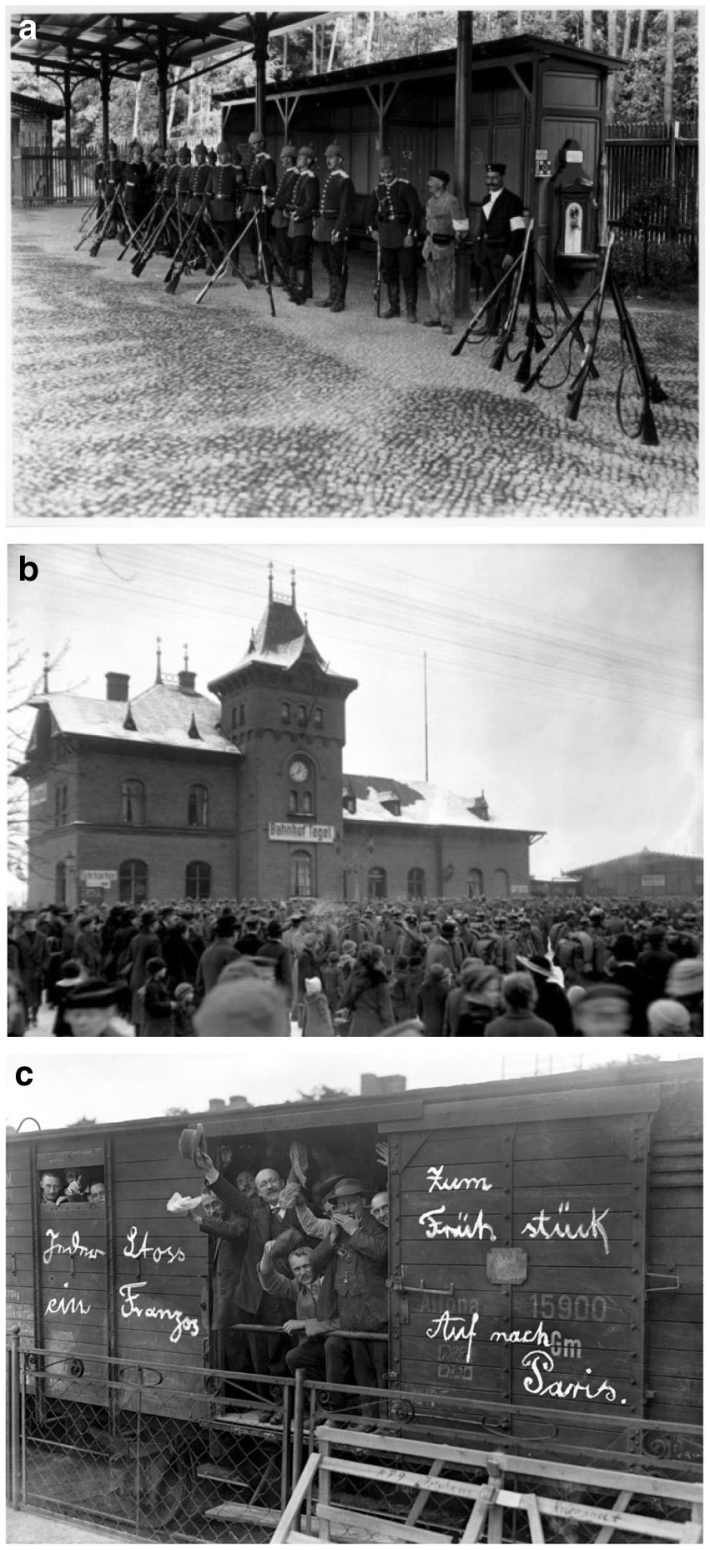

Fig. 3 a Occupation of railway stations in 1914 (Berlin). Photographer unknown. (C) Landesarchiv Berlin (F Rep 290 (03) Nr II9662). b Departure of the troops at Tegel railway station (near Berlin). Photographer unknown (C) Landesarchiv Berlin (F Rep. 290 (03) Nr. II7013). c Civilians departing in a goods train; the notes in chalk translate as "Each hit kills a Frenchman" and "To Paris for breakfast". Photographer unknown (C) Landesarchiv Berlin (F Rep. 290 (03) Nr II7027) 
in The World of Yesterday (Die Welt von Gestern, 1944) evoke are part of what Jan Assmann has termed "communicative memory": real experiences to which later generations can still relate with a strong sense of immediacy (Assmann 1995, 125-133). The above photographs reflect the typical scenes at the time: the occupation of stations; the departure of troops and finally the boisterous farewell with misguided illusions chalked on the wagons. They were reprinted time and again. For Toller's desire to belong and his nationalism the railway station is the perfect setting (Fig. 3a-c).

George Orwell's essay "My Country Right or Left" - with a number of themes he had already considered in his satire of 1939, Coming up for Air-was published in Folios of New Writing in 1940 and may be seen as an attempt to align a new sense of patriotism with the political views he had held so far. Seven years after Toller had made his memories of the outbreak of the First World War part of his autobiographical assessment of what it meant to be German, Orwell writes early on in a war that brought to a close the European interwar years and the hopes and disappointments that had been part of those two decades. The essay is from the outset an act of reassessing history.

It is the immediate human dimension of incidents that informs Orwell's memories of the outbreak of war-no matter whether these are real or imagined childhood memories of the event. There are the scandalized reactions of his elders to a cartoon of the German Emperor; the weeping cabman forced to part from a horse that had served him for many years; and finally:

[...] a mob of young men at the railway station, scrambling for the evening papers that had just arrived on the London train. And I remember the pile of peagreen papers (some of them were still green in those days), the high collars, the tightish trousers and the bowler hats, far better than I can remember the names of the terrific battles that were already raging on the French frontier.

$(1984,43)$

The war-related memory aside, this depiction of the station is a fair reflection of the practical role of railway stations well into the First World War: they were focal points of communication, where papers and foodstuff were delivered and transactions decided, all under the watchful eyes of semi-military staff who ensured the safe running of such places and of the railway system as a whole. Christian Wolmar describes their role by the end of the nineteenth century and up to the First World War:

Even the most modest station rapidly developed into the focus of the local community attracting not only passengers but greeters and traders, becoming the place of hellos and goodbyes, happiness and sorrow [...]. Whether it was in the United States or Britain, Japan or Mexico, the daily scenes of the movement of people and goods were similar. $(2009,265)$

In 1914 railway stations are local hubs - the natural reference point in terms both of transport and of information and therewith the natural destination for that " $\mathrm{mob}$ of young men" and the observer. 
However, by the 1940s, the association of the outbreak of war with railway stations implicitly affords, over and above the reality of their role, a more complex narrative well beyond July and August 1914. Reference to a station now marks the well-documented beginning of a shared European catastrophe. The symbolic value of a transitional space (of arrival, departure, in short the transience of life) is as important as the fact that it is firmly embedded between civilian and military lifethe one the young Orwell is part of, and the one he comes to crave. More than two decades on, the memory of the outbreak of war at a railway station serves as one of many snapshots that provide narrative short cuts in a topic too vast to depict in detail. The station is, by comparison, an agreeable point of reference in that it had served, for those who cared to see, as a point of visible communication beyond propaganda. This process of the translation of the experience of war back home begins during the war and continues well into the 1960s and 1970s. Examples include the German teacher and writer Maria Müller-Gögler in her memoirs of 1970 recalling the arrival of injured soldiers at the railway station in the Swabian town of Ravensburg (2001, 147-149); Leonhard Frank narrating in 1952 his wife's experience at the station in Konstanz contrasting cheerful music and the return of broken men $(2009,92)$; Alfred Polgar in one of his wartime feuilletons turning the railway station into a stove, year after year devouring soldiers never to return (1984, 41-44); or the German-Jewish writer Georg Hermann, who was to perish in a concentration camp, exploring the theme in 1921 on a literary railway journey from Berlin to Munich in the middle of the war (1997).

Orwell's evocation of the outbreak of the First World War in "My country Right or Left" is one of a world long gone-including the "tightish trousers", "bowler hats" and "peagreen papers". He is able to rely on the fact that his readers would set the association of initial shared emotions against the reality of later experiences. It is Orwell's prose-snapshots of daily life that turn the railway station into an image that implicitly harbours both the redundant illusions of the time and the knowledge of forthcoming destruction.

My last example refers to Berlin-born Julius Posener who studied architecture under Hans Poelzig and later worked with Erich Mendelsohn. Under the National Socialists he escaped first to Paris, then to Palestine and eventually registered with the British Army. Posener became a British citizen in 1946, taught architectural history in Kuala Lumpur and finally returned to Berlin. His first memoir, secretly written in English in the 1950s and preceding the more polished Fast so alt wie das Jahrhundert (published in 1990), appeared in a German translation by Ruth Keen for the first time in 2004. His recollections of the outbreak of the First World War need to be seen in the context of the life of a Jewish emigrant from National Socialist Germany who had experienced a relatively carefree and protected youth in a Berlin suburb. While Toller depicts a home-coming, and in Orwell's memory of the outbreak of war the railway station serves as a public meeting-point, Julius Posener's recollections relate to childhood memories that start with the First World War and then explore the first half of the twentieth century. For Posener the station serves as a reference point for a longer-term history that is marked by departurespersonal, those of family and friends and eventually long-held beliefs. This is a 
perspective shaped by two World Wars and knowledge of the destruction that was still to come.

The starting point for Posener's 1950s recollection about the First World War is the family's stay at the Dutch coast in the summer of 1914. It is only on departure on the 1 August 1914 that at the railway station war becomes, as for the young Zuckmayer, a reality:

Until deep into the night we saw one train after the other pass the stationwith singing and bawling recruits or troops in field grey, whose bayonets were decorated with flowers. The doors of the wagons showed chalk caricatures depicting the enemies France and Russia. Next to these images were slogans such as 'next stop Paris'. $(2004,55)^{9}$

These bawling soldiers and the chalk drawings Posener observes may well reflect the familiarity of well-known and much reprinted images-such as the image above-not necessarily a personal memory. Unavoidably the communicative memory Assmann describes has undergone changes here-what remains of the First World War are increasingly select moments. However, Posener's memoir is underpinned not just by images but also by similar observations of older contemporaries: the Alsatian Expressionist Ernst Stadler begins his war diary, a few months before he was killed in battle near Ypres on 30 October 1914, with a reference to occupied railway stations, singing recruits and onlookers waving handkerchiefs (Literaturmuseum 2014, vol. 2, 13); Hermann Hesse records the excellent atmosphere at the stations in Switzerland; Marie Luise Kaschnitz in the German cities of Karlsruhe and Mannheim (Hesse 2014, 28; Kaschnitz 2014, 87). Hotels close to railway stations meanwhile serve for many as observation and assembly points; like the railway stations they showcase the outbreak of war as a public event. The stock descriptions of a mood of exuberance underline a distinct sense of togetherness.

"What is called collective memory", Susan Sontag argues, "is not a remembering but a stipulating: that this is important, and this is the story about how it happened, with the pictures that lock the story in our minds." $(2008,76)$ In the 1950 s, four decades after the event, Posener is able to refer to the stock image of the railway station. The need to locate and visualize is part of the narrative that, internationally, determines communication about the War. In Posener's memories it is at the station that the all-decisive lines begin to be drawn: the "enemy", the hosts until the day before, are ridiculed for their tearful departures. In Posener's description the station is not only a de facto hurdle on the way home-it is also the place where the "otherness" of hosts turned enemies leads him to take sides. The station in Holland prompts a first deliberation of what for the time being remains an elusive abstract that the future refugee will seek to understand: war and, in due course, its memory. The recollection of the departure, the way writers dwell upon the process of transition (Schivelbusch's "threshold"), serves to dramatize the

\footnotetext{
9 Orwell's and Posener's observations share a further characteristic that links the collective experience with a personal one: while Orwell states that as a child the sinking of the Titanic had left a far greater impression on him than the whole war, Posener admits that in those years true angst was triggered rather by images about the French Revolution that he found in a book.
} 
experience of the beginning of war in perpetuity. It is the departures, not the returns, that have become ingrained in the public's mind.

Over the decades the memory of the outbreak of War at the railway station undergoes shifts: from the detailed account of the way home (Toller) to the childhood memory that serves as an entry-point to an assessment of current needs (Orwell) and the long-term national narrative (Posener). All three, writing at a point when their formative political years had peaked, share, however, one agenda: their view of history, punctuated by the alignment of personal and collective memories in one place, perceives wide-ranging twentieth-century developments set in motion there and then.

Railway stations serve our need to localize history. In Im Raume lesen wir die Zeit Karl Schlögel states that each time a political status quo is challenged the immediate response is the production of new maps-and that the ensuing reassessment of locations considers the togetherness (Nebeneinander), not the sequence of events $(2006,49)$. He argues that it is not epochs and the passing of time that matter but the cultural context-indeed, that physical locations are effective frames of reference in which it is possible to visualize what would otherwise be too complex to comprehend (10). To locate the memory of the outbreak of the First World War at the railway station serves this spatial understanding of history well: it is at the railway station that people gather, the event is no longer a mere abstraction and the subsequent departure enforces the awareness of belonging to a particular entity. Schlögel's approach to the eminence of physical spaces in historical terms can be aligned with Schivelbusch's evaluation of railway stations as locations of profound experiences. What is more, placing events at railway stations responds to our need not only to locate key events but, as Sontag has shown, to visualize them.

Even though the memories associated with the outbreak of War at the railway station unavoidably underwent change, as Toller, Orwell and Posener exemplify, the fundamental understanding remains. Gerhard Hirschfeld, assessing new approaches to the First World War, questions what entered the public's memory and how this memory was used after 1918 (2004, 9). The French term "guerre et cultures" (Becker et al. 1994) hints at the true dimension of such a question. For an understanding of the transformative scale of violence that masses of soldiers and civilians encountered, the railway station is among the most telling locations to start thinking about what was lost over 4 years. Despite the time that has passed, the location therefore remains one of poignant remembrance. After the arrival of the body of the Unknown Warrior on 10 November 1920, an unidentified First World War British soldier who would eventually be buried in Westminster Abbey, the coffin remained for one night on platform 8 in Victoria Station in London. The event is still commemorated in an annual service. In Paris, meanwhile, Albert Herter's mural of 1926 ("Le Départ des poilus, août 1914") is fittingly placed in the Gare de l'Est where mobilization of the troops started in 1914. Herter had himself lost his son to the war.

In the end the railway station is part of a narrative that begins in the nineteenth century, gains momentum at the beginning of the First World War and then extends deep into the twentieth century. In this way stations play a prominent role in the 
communicative memory that establishes, through the arts, its own visible and crossnational infrastructure. When in November 2014 the arrangement of poppies at the Tower of London drew millions in commemoration of the military casualties of the First World War, this visualization of a river of blood could just as fittingly have been placed at a railway station to mark the place from which soldiers in Britain and in all the other countries embarked on their fateful journeys. Semi-public spaces, in particular hotels and railway stations, facilitate national and cross-cultural narratives, they mirror national histories, but they also serve as points of understanding, illuminating events that have a global impact.

\section{Conclusion}

John Berger's observation that our knowledge determines what we choose to recognize is no doubt one reason why railway stations and hotels are the ideal conduit for local narratives: minor differences aside, these are functional institutions that in principle follow the same design wherever we are. But railway stations and hotels also serve to connect histories in that they allow us to "network" events. The narrative focus on railway stations and hotels takes advantage of the social and cultural microcosm each institution provides. This allows us, furthermore, to visualize links across countries: the building, flourishing, destruction and potential reopening of railway stations and hotels establish continuities that apply to all cultures.

Open Access This article is distributed under the terms of the Creative Commons Attribution 4.0 International License (http://creativecommons.org/licenses/by/4.0/), which permits unrestricted use, distribution, and reproduction in any medium, provided you give appropriate credit to the original author(s) and the source, provide a link to the Creative Commons license, and indicate if changes were made.

\section{References}

Assmann, Jan. 1995. Collective memory and cultural identity. New German Critique 65: 125-133.

Augé, Marc. 2006. Non-places. Introduction to an anthropology of supermodernity. London: Verso.

Baum, Vicki. 2007. Hotel Shanghai. Cologne: Kiepenheuer \& Witsch.

Baum, Vicki. 2008. Menschen im Hotel. Cologne: Kiepenheuer \& Witsch.

Becker, Jean-Jacques, et al. 1994. Guerre et cultures 1914-1918. Paris: Armand Colin.

Berger, John. 1972. Ways of seeing. London: Penguin.

Berger, Molly M. 2011. Hotel dreams: Luxury, technology, and urban ambition in America, 1829-1929. Baltimore: John Hopkins University Press.

Denby, Elaine. 1998. Grand hotels. Reality \& illusion. An architectural and social history. Chicago:

Chicago University Press.

Drewitz, Ingeborg. 1992. Bahnhof Friedrichstraße. Erzählungen. Hildesheim: Claasen.

Erll, Astrid. 2011. Kollektives Gedächtnis und Erinnerungskulturen. Stuttgart: J.B. Metzler.

François, Etienne, and Hagen Schulze. 2001. Deutsche Erinnerungsorte. Munich: Beck.

Frank, Leonhard. 2009. Links wo das Herz ist. Berlin: Aufbau.

Geisthövel, Alexa, and Habbo Koch (eds.). 2005. Orte der Moderne. Erfahrungsräume des 19. und 20. Jahrhunderts. Frankfurt/Main, New York: Campus.

Hedin, Sven. 1926. Von Pol zu Pol.Rund um Asien. Leipzig: Brockhaus.

Hermann, Georg. 1997. Doktor Herzfeld. Die Nacht. Schnee. Berlin: Das Neue Berlin. 
Hesse, Hermann. 2014. In August 1914. Literatur und Krieg, ed. Literaturmuseum der Moderne/ Deutsches Literaturarchiv Marbach, vol. 1, 27-29. Marbach am Neckar: Deutsche Schillergesellschaft.

Hirschfeld, Gerhard. 2004. Der Erste Weltkrieg in der deutschen und internationalen Geschichtsschreibung. Aus Politik und Zeitgeschichte 30: 3-12.

Kaplan, Justin. 2006. When the Astors owned New York. New York: Viking.

Kaschnitz, Marie Luise. 2014. In August 1914. Literatur und Krieg, ed. Literaturmuseum der Moderne/ Deutsches Literaturarchiv Marbach, vol. 1, 86-87. Marbach am Neckar: Deutsche Schillergesellschaft.

Kaschuba, Wolfgang. 2004. Die Überwindung der Distanz. Zeit und Raum in der europäischen Moderne. Frankfurt/Main: Fischer.

Literaturmuseum der Moderne/Deutsches Literaturarchiv Marbach, ed. 2014. August 1914. Literatur und Krieg. Exhibition Catalogue, vol. 1-3. Marbach am Neckar: Deutsche Schillergesellschaft.

Müller-Gögler, Maria. 2001. Geschichte einer Kindheit vor dem Ersten Weltkrieg. Ostfildern: Thorbecke. Neumann, Peter. 2004. Der absurdeste Bahnhof Berlins. Berlin: Berliner Zeitung.

Orwell, George. 1984. My country right or left. In Books v. Cigarettes. London: Penguin.

Özdamar, Emine Sevgi. 2001. Der Hof im Spiegel. Cologne: KiWi.

Pevsner, Nikolaus. 1979. A history of building types. London: Thames \& Hudson.

Polgar, Alfred. Bahnhof. In Kleine Schriften. Ed. Marcel Reich-Ranicki in co-operation with Ulrich Weinzierl, 41-44. Reinbek bei Hamburg: Rowohlt.

Posener, Julius. 2004. Heimliche Erinnerungen. In Deutschland 1904-1933, ed. Alan Posener. Berlin: Siedler.

Richards, Jeffrey, and John M. MacKenzie. 1986. The railway station. A social history. Oxford: Oxford University Press.

Ross, Corey. 2010. Media and the making of modern Germany. Mass communication, society and politics from the Empire to the Third Reich. Oxford: Oxford University Press.

Schivelbusch, Wolfgang. 2007. Geschichte der Eisenbahnreise. Zur Industrialisierung von Raum und Zeit im 19. Jahrhundert. Frankfurt/Main: Fischer.

Schlögel, Karl. 2006. Im Raume lesen wir die Zeit. Über Zivilisationsgeschichte und Geopolitik. Frankfurt/Main: Fischer.

Schmitt, Michael. 1982. Palast-Hotels. Architektur und Anspruch eines Bautyps 1870-1920. Berlin: Gebrüder Mann.

Sontag, Susan. 2008. Regarding the pain of others. London: Penguin.

Toller, Ernst. 1934. I was a German. The autobiography of a revolutionary. New York: Paragon House.

Volland, Jennifer M. 2013. Stay: The archetypal space of the hotel. In Grand Hotel. Redesigning modern life, ed. Jennifer M. Volland, Bruce Grenville, and Stephanie Rebick, 14-31. Ostfildern: Hatje Cantz and Vancouver Art Gallery.

Warf, Barney, and Santa Arias (eds.). 2009. The spatial turn. Interdisciplinary perspectives. London, New York: Routledge.

Wenzel, Maria. 1991. Palasthotels in Deutschland. Untersuchungen zu einer Bauaufgabe im 19. und frühen 20. Jahrhundert. Hildesheim: Georg Olm.

Wolmar, Christian. 2009. Blood, iron \& gold. How the railways transformed the world. London: Atlantic Books.

Zitzlsperger, Ulrike. 2013. Topografien des Transits. Die Fiktionalisierung von Bahnhöfen, Hotels und Cafés im zwanzigsten Jahrhundert. Oxford: Lang.

Zuckmayer, Carl. 1970. A part of myself. Portrait of an epoch. New York: Harcourt Brace Jovanovich.

Ulrike C. Zitzlsperger (MA, PhD Free University Berlin/Germany) is Associate Professor of German at the College of Humanities, University of Exeter (UK). Her work considers semi-public spaces such as hotels, railway stations and department stores and the cultural history of Berlin with a particular focus on the interwar period and the 1990s. 